\title{
A IMPORTÂNCIA DO MÉTODO ESCOLÁSTICO-TOMISTA DE ENSINO PARA O DESENVOLVIMENTO DA FORMAÇÃO UNIVERSITÁRIA
}

Claudio Pedrosa Nunes

Pós-doutor em Direito pela Universidade de Coimbra. Doutor em Ciências Jurídico-Filosóficas pela Universidade de Coimbra. Doutor em Direito do Trabalho pela Universidade de Salamanca. Professor Adjunto III da UFPB. Juiz do Tribunal Regional do Trabalho da $13^{a}$ Região. Autor do livro A Conceituação de Justiça em Tomás de Aquino: um estudo dogmático e axiológico entre outros. Articulista em diversas revistas jurídicas.

\section{Resumo}

O presente estudo se destina a apresentar algumas consideraçóes acerca do modelo escolástico-tomista de ensino e sua utilidade para o desenvolvimento da formação universitária em nível de graduação e pós-graduação em direito e áreas afins. Abordam-se as quatro etapas fundamentais do ensino escolástico-tomista (lectio, quaestio, disputatio e determinatio), examinando de forma minudente o perfil de cada qual e realizando as correspectivas conexôes para o desenvolvimento da instrução acadêmica como um todo. Faz-se referência à especial relevância que tal método de ensino ostenta mesmo na contemporaneidade, com inegável proveito no ensino jurídico, sendo improvável sua superação quando confrontado com outros modelos educativos.

\section{Palavras-chave}

Método; Escolástico; Ensino; Formação.

\section{Resumen}

El presente artículo contiene algunas consideraciones acerca del modelo escolástico tomista de enseñanza y su utilidad para el desarrollo de la formación universitaria a nivel de licenciatura y posgrado en el curso de derecho y disciplinas conexas. Trata de las cuatro etapas esenciales de la educación escolástica tomista (lectio, quaestio, disputatio y determinatio), con análisis detallada del perfil de cada cual, haciendo las conexiones pertinentes para el desarrollo de la instrucción académica en su conjunto. Se hace referencia a la especial relevancia que tal método ostenta en la actualidad, con sensible provecho en términos de enseñanza jurídica, e incluso su improbable superación ante otros modelos educativos. 


\section{Palabras clave}

Método; Escolástico; Enseñanza; Formación.

\section{Introdução}

O Século XIII notabilizou-se como o tempo de surgimento e apogeu das universidades e da sedimentação do cristianismo católico. A causa central de eclosão das universidades no Século XIII foi especialmente o desejo dos letrados de defender interesses e ideologias comuns, através de associaçóes corporativas. Com efeito, na Idade Média, a cultura e a civilização europeias passaram por significativas transformações, tendo como base a doutrina cristã católica e a difusão desta por meio de um regime de ensino bem definido.

A partir do Medievo, as descobertas científicas decorreram da efervescência da cultura e da necessidade de organização das cidades. Um novo mundo espiritual e cultural passara a constituir o dia a dia da comunidade. Nesse panorama, o ensino escolástico-tomista obteve especial destaque. Os métodos de ensino medievais constituíram induvidosamente um marco singular na história da cultura humana a partir daquele estágio temporal, mormente por conduto da doutrina pedagógica e das teorias do conhecimento de Tomás de Aquino expostas sobretudo na Suma Teológica.

A exposição exata e analítica dos problemas e discussōes, o esforço pela clareza e tecnicidade dos conceitos e definiçóes, a propriedade dos silogismos e o emprego universal do latim são aspectos ímpares daquele regime didático-pedagógico jamais superado. As universidades medievais, por seu turno, inspiraram-se também na conveniência de reunião dos sábios de então, dando-lhes oportunidade de ingressar formalmente no corpo docente dessas instituiçóes e difundir seus conhecimentos com grau de oficialidade, isto é, como mestres oficiais do saber.

É nessa perspectiva que o presente artigo se desenvolve. O objetivo central é apresentar ao interlocutor uma ideia clara e precisa o quanto possível de um modelo de ensino e aprendizado que se identifica pela participação eclética de todos os envolvidos no alcance do saber literário e científico, não obstante sob a autoridade do docente. Mais que isso, o ensino escolástico medieval-tomista houve por bem projetar-se no tempo não por uma simples questáo de comodidade dos estudiosos e preclaros ou de mera repetição de políticas de educação, mas especialmente por sua elevada propriedade e eficiência no revelar o saber.

\section{Propedêutica do Ensino Escolástico-Tomista}

No alvorecer do método universitário escolástico-tomista de ensino, mister perpassar um breve olhar sobre a formação e evolução das escolas medievais regulares, realçando 
as suas propriedades e utilidades didáticas e demonstrando as conexôes pertinentes para efeito de surgimento efetivo das universidades medievais. Vejamos.

\subsection{Perfil das Escolas Medievais Pré-Universitárias}

As escolas medievais mais conhecidas antes da formação oficial das universidades eram as monásticas, presbiterais, episcopais e palatinas ou palacianas. (ULLMANN, 2000, P. 32). As escolas monásticas eram voltadas ao ensino e vida puramente religiosos, estando destinadas sobretudo à formação de religiosos e sacerdotes. Foram edificadas tanto no Oriente quanto no Ocidente. Como era característico das escolas monacais, o ensino e a educação eram dirigidos à formação espiritual mais que à intelectual. Aloysio Ullmann (2000, p. 32-33) menciona como “exímios educadores”, nesse estágio, São Pacômio (292-342) e Santo Antônio de Tebas (251-356), contrários ao ensino dos gnósticos. A Bíblia era recitada de cor e entendida como fonte de alimento espiritual.

As escolas presbiterais ou paroquiais tiveram sua importância reconhecida no II Concílio de Vaison, datado de 529, quando passou a ser exigido que todos os curas rurais recebessem meninos na casa paroquial com objetivo de lhes ministrar a doutrina cristã, através do estudo dos Salmos e demais escrituras, de forma a encaminhá-los ao trabalho paroquial. (AQUINO, 2009).

O ensino nas escolas presbiterais avançou para jovens sem vocação sacerdotal, podendo então ser aproveitados como servidores úteis para o Estado. Tal ambiente paroquial tem origem visível na Itália, sendo da simpatia dos nobres que desejavam a educação formal de seus filhos. A prática presbiteral consistia em ler, contar, escrever e conhecer passagens da Bíblia, aprender os Salmos, além de preparar discursos bíblicos, se possível. Não havia estudo da cultura clássica, sendo a Bíblia o único livro destinado à leitura e estudo. Como visto, tratava-se de estudo paroquial das escrituras, talvez um pouco mais que os atuais "catecismos", tudo sob a iniciativa e a direção de um pároco.

As escolas episcopais, por sua vez, destacaram-se sobretudo diante da perda de prestígio das escolas monacais. Segundo Ullmann (2000, p. 41), as escolas episcopais foram criadas por Santo Crodegango, por volta do ano 750 d.C. Essas escolas eram destinadas especialmente à formação de sacerdotes, não obstante tivessem permitido o ingresso de leigos, com a "schola exterior". (ULLMANN, 2000, p. 41). A formação de presbíteros, entretanto, não era das melhores, conjugando-se às imprecisóes próprias dessas escolas pré-universitárias. Apesar disso, as escolas episcopais evoluíram sobretudo no Século XII e eram coordenadas por um escolástico, sob a supervisão e autoridade superior de um bispo.

As escolas palatinas, por derradeiro, eram aquelas conjugadas aos palácios dos reis, destinadas ao ensino dos filhos dos nobres. Coube especialmente a Carlos Magno imprimir 
dinâmica a essas escolas, tendo, por isso, recebido reconhecimento com o apíteto de "restaurador das belas artes clássicas", inaugurando o chamado renascimento carolíngeo. (ULLMANN, 2000, p. 45). Não era incomum que os próprios pais acompanhassem os filhos nas aulas, inclusive os reis, até porque muitos destes tinham pouca ou quase nenhuma instrução. $\mathrm{O}$ conteúdo das aulas dessas escolas palacianas envolvia o trivium e o quadrivium, admitindo-se padres e leigos no seu desenvolvimento. Predominava o uso do latim, que já se destacava como expressão linguística cultural, facilitando o ensino nas escolas medievais de todos os reinos e, ao mesmo tempo, permitindo afinidades culturais entre a Igreja e o Estado.

\subsection{Programa Didático e Projeto Universitário}

Todas essas escolas medievais pré-universitárias reuniam um programa semelhante de estudos, não obstante se verificassem algumas diferenças pontuais. É sensível a preocupação da Igreja com a formação moral de seus discípulos, ao mesmo tempo em que pretendia a divulgação e a universalização da doutrina cristã. Para isso, a Igreja necessitava sedimentar a base de uma cultura que a identificava. $\mathrm{O}$ ensino era, portanto, de grande importância e utilidade para a Igreja, eis que representava a afirmação de sua doutrina em nível universal e a fortalecia como instituição mais respeitada e reconhecida em termos de civilização ocidental, como realça Bellomo (1997, p. 427).

No programa de ensino de responsabilidade da Igreja, destacaram-se as chamadas artes liberais e as artes principais ou iliberais. As artes liberais eram consideradas propedêuticas, isto é, uma iniciação ao estudo formal conducente à preparação necessária para ingresso no estudo das cadeiras essenciais. As artes liberais subdividiam-se em trivium e quadrivium. O trivium compreendia a gramática, a retórica e a dialética ou lógica; o quadrivium, por sua vez, compreendia a aritmética, a música, a astronomia e a geometria. Assim se tem o programa básico de ensino proporcionado pela Igreja Romana. Este programa básico de ensino de iniciativa da Igreja informou com grande proveito a ação dos docentes e representou o marco fundamental de rompimento do estado de ignorância e depravação dos costumes de então no Ocidente civilizado.

No tocante ao trivium, destacava-se uma modalidade peculiar de discussóes, inserida na retórica, que era a tópica. A tópica consistia fundamentalmente na problematizaçáo do discurso, investigando-o à exaustão até se alcançar o mais próximo de uma afirmação segura. Não se confunde, entretanto, com a quaestio e com a disputatio (segmentos do método escolástico de ensino) porque se destina a corrigir antagonismos do próprio discurso ou de dois ou mais discursos, como sugere Viehweg (1986, p. 100-101). Para o notável jurisconsulto germânico, a tópica representara um desafio para a então jovem cultura medieval diante de dois aspectos fundamentais: a) como resolver a questão da contradiçáo 
entre dois textos estudados nas escolas e universidades medievais; b) como correlacionar assuntos ou teses coerentes de discursos diferentes.

Para Viehweg (1986, p. 104), o emprego da tópica é fundamental para a correta interpretação de textos e discursos, assim como de leis e pronunciamentos judiciários. Com efeito, a problematização dos discursos reclama uma solução e esta só pode ser obtida a partir das concordâncias que se extraem do exame tópico (problematização) desses discursos. (VIEHWEG, 1986, P. 101). Uma das mais prestigiadas soluções em meio à tópica (que conduz ao encontro das concordâncias) é a chamada hierarquia de autoridades, uma prática bem conhecida em todo o Medievo. Assim, a autoridade docente ou científica é o norte das concordâncias, não porém sem um exame das ideias expostas nos textos em debate. (VIEHWEG, 1986, p. 101). Numa esquematização da tópica, Viehweg (1986, p. 101-102), faz menção à forma clássica adotada por Tomás de Aquino, conforme se demonstra:

(1) utrum ... (fixação do problema);

(2) videtur quod ... (pontos de vista coincidentes);

(3) sed contra ... (dissensos);

(4) respondeo dicendum ... (solução).

A conjugação dessas estruturas certamente resultou na organização de um ensino mais oficializado, avançado e científico em comparação com o ensino puramente religioso, conforme sugere Pepin (1995, p. 257). A universalização do ensino e do aprendizado foi portanto o diferencial que elevou as escolas pré-universitárias a nível de universidades, atraindo os estudiosos à reunião de conhecimentos para além da pura doutrina da Igreja Romana. E, nesse quadro, houve necessidade de introduçáo de nova política pedagógica, alheia aos limites didáticos até então em voga.

\section{As Universidades e sua Estrutura Escolástico-Tomista}

Como visto, as escolas monacais, presbiterais, episcopais e palacianas constituíram a fase embrionária das universidades medievais, permitindo uma formação adequada e proporcionando a definição de uma estrutura didática mais aperfeiçoada. Houve, por assim dizer, uma oportuna fase de transição no ensino da época, conferindo inegável eficiência ao ensino universitário, cujo marco exuberante coincide com a escolástica tomista.

\subsection{Formação e Constituição das Universidades}

Na Idade Média o termo "universidade" obviamente não se revestia da estrutura que hoje ostenta. Para sua formação e constituição, a universitas concentrava a formalização de 
simples curso ou faculdade de linguagem moderna (para a época) que conseguisse reunir um grupo de alunos e professores. Assim, os studium e os collegia também gozavam do status de universidade. $\mathrm{O}$ merecimento da condição de universidade intensificava-se com a presença de mestres ilustres, alguns dos quais tiveram seus nomes vinculados diretamente a escolas que se transformaram rapidamente em universidades. Exemplo clássico é o de Alberto Magno, cujo nome foi suficiente para a fundação do studium de Colônia. Outros mestres também se destacaram no particular, a exemplo de Pedro Abelardo, em Paris e Bolonha, e Irnerius, mestre em Direito.

Os studium também eram instalados como extensóes das universidades, com objetivo talvez de expansão internacional. Os studium mais conhecidos e importantes, como visto, eram aqueles instalados em Colônia (Alemanha), assim como no interior da França e da Itália. Como assinala Asztalos (1996, p. 416), os studium eram faculdades internacionais sobretudo de teologia e foram desenvolvidos a partir das universidades de Paris, Oxford e Cambridge. Era conveniente que cada ordem religiosa instalasse seu próprio studium, conquanto fosse difícil imaginar alguma ordem sem relação de proximidade com o estudo da teologia.

De todas as escolas pré-universitárias precedentemente estudadas, foram as escolas catedralícias ou palacianas as que ofereceram as melhores condiçóes para tornar-se universidades. Contavam elas com o diferencial da localização em área urbana, além da reconhecida eficiência didática. As escolas palacianas possuíam, portanto, estrutura física e didática de referência, obviamente porque se encontravam mais próximas da corte real, logrando proveito nesse aspecto.

Mas qual teria sido a causa central e essencial para a formação e constituição das universidades medievais? Na verdade, não há uma causa específica e fundamental que, por si só, tenha sido considerada o marco essencial e preciso da formação das universidades no Medievo. Afirmamos que a conjugação de várias concausas contribuiu decisivamente nesse particular. Destacamos a seguir as principais concausas.

Um primeiro aspecto corresponde ao surgimento das cidades ou conglomerados urbanos, influenciados pelo comércio marítimo no Mediterrâneo ${ }^{1}$. Nesse contexto, viram-se os comerciantes estimulados a estabelecer-se em pontos sensíveis e estratégicos de circulação de mercadorias, cuja população se concentrava e também se constituía de estudantes. (SANTIDRIÁN, 1983, p. 15). A formação de uma burguesia incipiente, assim, parecenos um marco importante contributivo da constituição da universidade no Medievo.

As investidas das Cruzadas também podem ser mencionadas como fato importante ensejador da origem das universidades medievais. Isto porque as Cruzadas proporcionaram

1 No século XIII, o regime de economia feudal encontrava-se em declínio, sendo substituído pelas novas corporaçōes de ofício, fazendo dos centros urbanos os principais núcleos de comércio. 
contato mais aproximado entre as culturas da Europa e do Oriente, despertando a curiosidade e estudo científico dessas culturas numa espécie de universalização do conhecimento das variadas culturas. (ULLMANN, 2000, p. 112).

A necessidade de Papas e Imperadores cercar-se de homens sábios e cientistas é também interessante aspecto a ser abordado no tocante à formação das universidades medievais. Premidos pela limitação do saber, precisavam ter em contato permanente estudiosos que lhes orientassem na arte da guerra e no domínio das letras, já que em evidência o surgimento do Renascimento. Assim, as escolas pré-universitárias passaram a receber estímulos dos Papas, Imperadores e Reis, transformando-se em instituiçóes clericais e estatais, com estruturação de gastos e organização didática. O trivium e o quadrivium restaram insuficientes no domínio do saber em razão do surgimento e desenvolvimento de novas "ciências" como a Filosofia, a Teologia, o Direito e a Medicina, o que demandava o fortalecimento e a ampliação das escolas.

Fervilhava, concomitantemente, a criação de grêmios de estudantes, corporaçóes de trabalhadores com objetivo de defesa e conquista de direitos, o que reclamava emprego de técnicas de dialética e formulação de silogismos. Havia ainda a necessidade de congregar-se diversas pessoas de todas as origens e ofícios, tais como padres, frades e leigos que procuravam instrução. (ULLMANN, 2000, p. 112-113). Tal ambiente serviu inclusive de importante iniciativa de mitigação dos rigores das distintas classes sociais, muito em voga na Idade Média, proporcionando, ao menos em nível de ensino universitário, oportunidades iguais e convivência amistosa entre ricos e pobres, alunos e mestres. As universidades medievais inspiraram-se também na conveniência de reunir-se os sábios de então, dando-lhes oportunidade de ingressar formalmente no corpo docente dessas instituiçóes e difundir seus conhecimentos com grau de oficialidade, isto é, como mestres oficiais do saber.

É sensível, destarte, que cada um desses fatos-aspectos da cultura da época foi indispensável, talvez em grau de igualdade, à formação e constituição oficial das universidades medievais. Foi o conjunto desses fatos-aspectos que garantiu a rápida e oportuna construção da cultura e do saber universitário. E isto sem dúvida instigou as autoridades a enveredar com urgência nesse domínio, até como forma de preservar sua autoridade de governante através do desenvolvimento e da oficialização das instituiçóes do Império por conduto e com auxílio da Igreja Católica Romana.

Importa ainda ter em consideração a forma em que se deu a formação e a estruturação das universidades medievais, tendo em vista o ato, formal ou informal, deflagrador desse processo. A formação das universidades medievais ocorreu diante de fenômenos que resultaram na necessidade de seu reconhecimento como instituição oficial. É dizer que, verificada a conjugação das concausas ora estudadas, resulta importante consignar a natureza dos fatos e/ou atos formais que conduziram diretamente à formação, fundação, 
constituição e oficialização das universidades medievais como instituiçóes permanentes do Estado e da Igreja.

Em primeiro lugar, algumas universidades medievais surgiram espontaneamente, isto é, como resultado da evolução e desenvolvimento das escolas pré-universitárias. A transformação dessas escolas em universidades advinha de permissão sobretudo do Papa diante do reconhecimento da autoridade didática dos professores nelas inseridos. Exemplo desse tipo é a Universidade de Paris e outras que se tinham formado até 1290, tais como Bolonha, Oxford, Salamanca, Coimbra² etc.

Um segundo grupo de universidades medievais surgiu não da evolução de escolas pré-universitárias, mas de ato formal do Papa e/ou do Imperador, geralmente por motivos predominantemente político-religiosos (auctoritate). Por este meio formal, não se olvida que a universidade era resultado da conscientização da importância que ostentava para a formação de pessoal de apoio ou de assessores intelectualmente preparados. Exemplo típico desse tipo de universidade é a Universidade de Nápoles.

Uma curiosidade digna de registro quanto à criação ex privilegio da Universidade de Nápoles é que esta foi idealizada para superar a Universidade de Bolonha, que acolhia vários estudantes da antiga e esfacelada Itália. (TORREL, 2004, p. 7). Para desprestigiar e esvaziar a Universidade de Bolonha, Frederico II proibiu a transferência de professores e alunos da Universidade de Nápoles para aquela outra universidade, o que causou dificuldades para a própria escola de Nápoles. Outra universidade ex privilegio foi a de Toulouse, originária de iniciativa dos Papas Honório III e Gregório IX, cujo objetivo era combater a heresia dos cátaros no começo do Século XIII.

Durante toda a Idade Média, especialmente nos Séculos XII e XIII, viu-se o surgimento de diversas universidades, seja ex consuetudine, seja ex privilegio, muitas das quais conservam até hoje a mesma excelência didática. Assim, como bem anota Ullmann (2000, p. 113-114), a pretensa "Idade das Trevas" não é senão alcunha maliciosa daqueles contaminados por indisfarçável preconceito ou ignorância intelectual, muitas vezes rotulados de "modernistas" e "democráticos", e que não passam de intelectualistas corrompidos pela parcialidade.

\subsection{A Universidade de Coimbra}

No tocante ainda às universidades medievais, importa fazer referência especial à Universidade de Coimbra. Fundada em 1290, por Dom Diniz, também se insere como

2 Segundo o guia da Faculdade de Direito da Universidade de Coimbra (2001-2002, p. 11), "Os estudos jurídicos remontam, em Portugal, à fundação da Universidade, durante o reinado de D. Diniz. A data exacta de sua criação situa-se, com certeza, entre 1288 e 1290. É tradicional, embora não isento de controvérsia, o ponto de vista que reconhece a instituição do Studium Generale na carta dionisiana de 1 de Março de 1290". 
consequência da efervescência cultural da Europa Medieval. Mais que isso, entretanto, a Escola de Coimbra representou um divisor de águas entre a letargia cultural que predominava em Portugal no Século XIII e o salto de ensino que ali promoveram os escolásticos. Certo que nos seus primórdios, os studium conimbricensis ainda se ressentiam da letargia cultural. Ao tempo de sua criaçáo, as escolas que havia em Portugal eram, praticamente, as escolas monacais e as escolas episcopais.

Ao contrário do que sucedia na Europa central, Portugal encontrava-se em franco isolamento cultural até a reformulação e incremento dos studium conimbricensis, como anota Saraiva (1950, p. 47). Somente em 13 de agosto de 1290 efetivamente surgiu, ex

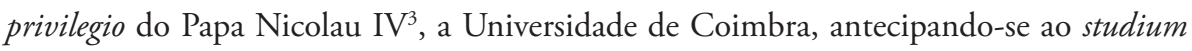
universitae que seria instalado em Lisboa. A bula De Statu Regni Portugaliae autorizava expressamente o magistério em Direito Canônico e em Direito Romano.

Os graduados em Coimbra estavam autorizados a lecionar em qualquer lugar do mundo cristão. $\mathrm{O}$ status formal de universidade conferia aos então studium conimbricensis os privilégios das grandes universidades européias medievais: estrutura física e didática, quadro de professores universitários condignamente remunerados, além da missão de difundir a ciência e formar o clero à altura de sua missão a serviço de Deus. Não obstante, a Universidade de Coimbra não era muito conhecida do resto da Europa, até que, por iniciativa de Dom Diniz, inauguraram-se alguns programas do sistema de Bolonha, conferindo a Coimbra a destinação de alguns estudantes estrangeiros, mormente italianos. (ULLMANN, 2000, p. 305).

Contudo, foi no Século XVI que a Universidade de Coimbra ganhou notoriedade mundial, não por acaso, mas diante do trabalho incessante e prestigioso de mestres escolásticos tomistas como Pedro da Fonseca (1528-1599), Manuel de Góis (1543-1597) e, principalmente, Francisco Suárez (1548-1617). Durante todo o Século XIII, no entanto, em pleno alvorecer das universidades medievais, Coimbra permaneceu ofuscada como verdadeira escola universitária integrada ao restante da Europa culta, talvez pelo fato de suas constantes alteraçóes de local, oscilando entre Lisboa e Coimbra, tornando-a de identidade indefinida até mesmo em Portugal. (LISBOA, 1993, p. 15).

Em que pese as turbulências enfrentadas, a Universidade de Coimbra tornou-se exuberante a partir sobretudo do reinado de Dom João III, tendo-se transformado em expoente da cultura do mundo civilizado. Não hesitamos asseverar que o embriáo escolástico tomista que constituiu essa importante escola do saber certamente é o diferencial da excelência de sua tradição em estudos filosóficos.

3 Ato oficial consubstaciado na Bula De Statu Regni Portugaliae (Cf. Enciclopedia luso-brasileira de cultura, Lisboa: Editorial Verbo, 1964, p. 483). 


\subsection{Avanço Dominicano}

No contexto da formação e constituição das universidades medievais, as faculdades dominicanas ganharam influência e importância com o passar dos tempos, o que causara alvoroço entre os mestres seculares que, dispersos e com dissensos, favoreceram exatamente o desenvolvimento das escolas teológicas dos padres mendicantes. Foi dessa sucessão de fatos que São Boaventura firmou-se como mestre universitário. (ASZTALOS, 1996, p. 417). A igualdade de cátedra em relação aos mestres seculares ampliou-se a partir do momento em que os predicadores passaram a recrutar entre os seus aqueles que se destacavam nos estudos e demonstravam vocação docente. Talvez tenha sido esse o marco fático fundamental que favoreceu o acirramento dos ânimos entre os seculares e os mestres mendicantes, conforme sugere Asztalos (1996, p. 417). Tal acirramento de ânimos acentuouse pela confirmação da autoridade e preparo acadêmicos de muitos dominicanos, entre os quais se destaca Tomás de Aquino.

Um dos episódios mais marcantes que sedimentou o reconhecimento do preparo erudito dos mendicantes registrou-se nos enfrentamentos entre Tomás de Aquino e o secular Gerardo de Abbeville em 1272, cuja celeuma envolvia a possibilidade de admissão de rapazes nas ordens religiosas e na faculdade de artes. A tese tomista resultou vencedora. Discutia-se ainda com calor questóes como a dignidade da pobreza e da resignaçáo dos homens, além das virtudes da perfeição espiritual. (ASZTALOS, 1996, p. 417-418).

\subsection{Desenvolvimento da Formação Universitária Medieval}

Importa ressaltar, outrossim, a composição curricular dos mestres para fins de investidura na função de docente, o que foi motivo de grandes enfrentamentos entre predicadores e seculares. Havia costume sedimentado nas universidades segundo o qual o docente somente poderia tornar-se mestre em teologia se houvesse cursado a faculdade de artes. Era uma espécie de pré-requisito para a docência em teologia. Entretanto, Tomás de Aquino assumira a docência em teologia não só antes da idade adequada prevista estatutariamente como também sem se haver diplomado na faculdade de artes. Era uma inovação radical que veio a romper com uma tradição já incorporada oficialmente no ensino universitário de então.

Antes de tornar-se docente em teologia, o acadêmico deveria passar por fases docentes anteriores, quais sejam: a) cursor biblico; b) bacharel sentenciário; c) bacharel formado; d) magister in sacre pagina (mestre em teologia). (ASZTALOS, 1996, p. 419). Os dominicanos, entretanto, nem sempre atuavam como cursor biblico tendo em vista que sua atividade de pregação em público era de importância tal a autorizar dispensa daquela atividade especulativa. Assim, os dominicanos eram alçados mais cedo à docência, haja 
vista a formação diferenciada que tinham em termos de grade curricular. Não é difícil perceber que tal fato também constituía motivo de desavença com os seculares.

$\mathrm{Na}$ faculdade de teologia havia um método específico de ensino em relação àquele adotado no ensino escolástico em geral. Não havia figa radical à lectio, quaestio, disputatio e determinatio, mas, dentro destas, eram acrescidos o que podemos considerar submétodos ou singularidades no ensino da teologia. Assim é que, como bem anota uma vez mais Asztalos (1996, p. 421), tinham-se: a) aulas; b) disputas; c) sermóes. Esses submétodos oscilavam a depender da natureza das obras teológicas postas em estudo. Os submétodos em comento evidentemente estão mais afeitos à lectio e à quaestio, de modo que é possível concluir que se apresentavam como estágio inicial do ensino teológico.

Fato curioso em relação ao ensino escolástico está relacionado com as artes, isto é, aquele ciclo básico de estudos que precede ao ensino da teologia propriamente dita. É que a faculdade das artes era destinada ao ensino das chamadas ciências naturais (medicina, direito, astronomia, geometria, gramática, retórica, lógica etc). Porém, no método de ensino das artes avançava-se aqui ou acolá pelas questôes religiosas e, portanto, teológicas. Tal prática acabava por questionar a autoridade dos dogmas teológicos, mormente quando as demonstraçóes das práticas punham em evidência verdades teológicas.

Diante disso, a partir de 1272, por disposição estatutária, proibiu-se qualquer incursão teológica nas faculdades de artes, designadamente questốes como a encarnação e a Trindade. Não há como olvidar que tal situação culminou no acirramento dos ânimos em Paris entre mendicantes e seculares. Houve, pois, teses condenadas e proibidas oriundas das artes, não obstante se fizessem reunióes secretas para desenvolvimento dos debates nelas inseridos.

Entre as teses condenadas, uma das mais destacadas foi de autoria de Sigério de Brabante (1284) e Boécio de Dácia (1284), as quais proclamavam: a) eternidade do mundo; b) fatos naturais dependentes do movimento dos corpos celestes; c) a morte elimina a alma do homem. O ambiente de condenaçóes de teses, refutações e enfrentamentos entre mendicantes e seculares não impediram Tomás de Aquino de alçar a teologia à categoria de ciência. Na escolástica tomista, a teologia passara à mais elevada categoria do ensino, ostentando a qualidade de disciplina científica. (ASZTALOS, 1996, p. 424-425).

Toda a atmosfera palpitante proporcionada pelo surgimento e apogeu das universidades não retirou do Século XIII as características de um tempo pautado pela tranquilidade da ordem social e estabilização política, não obstante a ocorrência de certos fatos culturais e científicos que causaram impacto no pensamento teológico-filosófico de então. Anota Chevalier (1956, p. 288), com acurada precisão, que o Século XIII também fora a época de iniciação da adesão da filosofia ocidental ao pensamento de Aristóteles, bem como do surgimento da filosofia da razão (ratio), tudo sob os auspícios da doutrina 
teológico-filosófica do Angélico. O mesmo autor destaca ainda a vida e a obra de Santo Tomás como um dos mais perfeitos momentos do pensamento humano e cristáo. (CHEVALIER, 1956, p. 288-289). A fidelidade ao pensamento racional faz de Tomás de Aquino o doutor da ponderação, do equilíbrio e da coerência de pensamento que marca toda a história da Cristandade.

\section{Método do Ensino Escolástico-Tomista}

Após tratarmos do desenvolvimento da formaçáo universitária medieval, mormente no tocante à formação docente e à prática do ensino, é importante destacar os principais pormenores do método escolástico-tomista de ensino, enfatizando a atuação especial de Tomás de Aquino. Vejamos.

\subsection{Lectio, Quaestio, Disputatio e Determinatio}

O método escolástico de ensino constituiu o apogeu das políticas eficientes de ensino adotadas na Idade Média. Diríamos que significou a fonte de inspiração e irradiaçáo que fez nascer e prosperar o próprio Renascimento. Partira da lectio e das questiones ou quaestio bem desenvolvidas nas escolas monacais, episcopais e palacianas para, aperfeiçoando o ensino e o aprendizado, acrescentar a disputatio e a determinatio.

A lectio e a quaestio desenvolviam-se da mesma forma do que sucedia naquelas escolas pré-universitárias, cujo diferencial não era senão o aprofundamento e a evolução da interpretação e comentários aos textos de filosofia, teologia, direito e medicina. As explicaçōes e comentários do mestre eram seguidos da formulação de questôes para fomentar o debate (quaestio). Ato contínuo, as argumentações eram postas em discussão em que os alunos expunham seu entendimento e críticas ao professor, assemelhando-se à maiêutica desenvolvida por Sócrates na filosofia grega. (VERGER apud ULLMANN, 2000, p. 61).

Em Paris, com o avançar da disputatio, o ensino universitário dividiu-se em ordinário e extraordinário. $\mathrm{O}$ ensino ordinário era ministrado sobretudo pela manhá, pelo mestre, com destaque para apresentaçáo do que hoje podemos considerar uma teoria geral de cada disciplina. Já o ensino extraordinário ocorria no turno vespertino, sendo ministrado por bacharéis, cuja base era a revisão e aprofundamento dos assuntos expostos pela manhã. As disputas ou discussões também se distinguiam em ordinárias e extraordinárias, a depender da importância que ostentavam.

As disputas ou discussóes ordinárias realizavam-se semanalmente e serviam também como reforço ou fixação do aprendizado; as extraordinárias ocorriam em ocasiôes solenes, ligadas a um ou outro evento anual importante e digno de grande celebraçáo, a exemplo do Natal, Ano Novo e Páscoa. As disputas ordinárias desenvolviam-se sobre assuntos 
previamente escolhidos pelo professor, que também indicava um ou mais alunos que deveriam atuar ${ }^{4}$. Sertillanges (1946, p. 80) expóe que havia significativa adesão do povo, o qual acompanhava atento todo o desenrolar das discussóes.

Contra os defendentes estavam os opponentes, cuja missão era opor-se aos argumentos dos defendentes com objetivo de desautorizar-lhes nas invocaçóes. Tanto a defesa dos assuntos quanto as oposiçóes decorriam em latim, idioma tradicional no Medievo, sob a forma de silogismos. Aliás, a Suma Teológica de Tomás de Aquino é excelente demonstração da propriedade desses silogismos e do grau de riqueza e precisão dos debates. As disputas extraordinárias, não obstante seguissem o mesmo ritual das ordinárias, contavam sempre com a presença de grandes mestres e autoridades acadêmicas, que se debruçavam sobre questôes palpitantes da atualidade de então. Tomás de Aquino não se furtou a essas instigantes disputas, no que sempre demonstrava a propriedade e acerto de suas elucubrações. (ULLMANN, 2000, p. 65). As disputas nem sempre ocorriam de forma ordeira, isto é, não raro as discussóes se faziam ao mesmo tempo, com "defendentes" e oppositores argumentando ao mesmo tempo.

A determinatio, estágio seguinte do método de ensino universitário medieval, servira não só para ordenar as discussóes nas questiones disputatis, mas, especialmente, para determinar qual a tese vencedora, por expressar com mais propriedade acadêmico-dogmática e precisão silogística os argumentos estabelecidos. Ao termo das questiones disputatis, o professor, ao firmar a determinatio ou solutio, punha a "verdade" a ser acolhida e respeitada, considerando a segurança dos argumentos vencedores. Tal determinatio magistri era convertida em obras dispersas denominadas questiones disputatae.

Ao lado das questiones disputatis seguidas da determinatio, havia ainda as questóes travadas entre professores na presença de seus alunos. Ao contrário do que se possa imaginar a princípio, esses eventos náo se destinavam a descobrir ou verificar qual o professor mais qualificado nas questóes em debate, mas para aprofundamento do aprendizado dos scholars através do embate entre diferentes professores. Os estudos se estendiam até em períodos de recesso das universidades, logo após a conclusão das liçóes dos mestres em determinados períodos. A iniciativa era adotada sobretudo para os estudantes mais adiantados e para aqueles que desejavam alcançar formação em teologia.

\subsection{Tomás de Aquino e as Disputas Jusfilosóficas}

No âmbito do ensino do direito, a lectio e as questiones disputatis eram acrescidas das harengas (arengas), cujo objetivo era explorar discursos capazes de preparar os futuros

4 Tais alunos eram os "defendentes" ou "respondentes" (Cf. ULLMANN, Aloysio. In: A universidade medieval, op., cit., p. 65). 
bacharéis para o bem falar e para construir silogismos de defesa ou acusação em determinada matéria. Era comum, nos cursos de direito, produzir-se comentários às leis, no que se formaram os glosadores e os pós-glosadores, ou seja, os versados nessa arte. Ainda hoje é induvidosa a autoridade e a utilidade dos comentários aos códigos jurídicos, tornando a interpretaçáo de textos legais o resultado de trabalho de investigação promovido por autoridades jurídicas de renome. A própria Suma Teológica não refoge visceralmente de tal sistemática, debruçando-se Tomás de Aquino sobre questóes e passagens importantes das Sagradas Escrituras, resultando em conclusóes adequadas e solucionadoras de muitos problemas jurídicos e sociais que eclodiram naquela época de significativas transformaçôes.

A autoridade acadêmica do aquinatense representou, sem dúvida, importante diferencial para o inegável sucesso do trabalho hermenêutico dos comentadores. Sequenciando essa prática de comentários de textos de leis, os glosadores, a partir do Código de Justiniano, voltavam-se a explicar a exegese de cada palavra ou expressóes dos textos jurídico-legais5. O objetivo logicamente era explorar o sentido que encerravam e penetrar a intenção dos legisladores, do que resultaram as glosas interlineares e as glosas marginais. Juan, o Teutônico, revelou-se como um dos mais conhecidos e famosos glosadores, tendo lecionado sobretudo na Itália.

Francesco Accurcio talvez tenha sido o mais famoso entre os glosadores (1182 a 1260), já que foi o responsável pelas glosas apostas junto ao Corpus Iuris Civilis de Justiniano. (CARPINTERO, 2004, p. 11). Entre as principais obras subjacentes ao ensino universitário medieval, destacaram-se obviamente as de filosofia e teologia. Entre tais obras, estavam as chamadas Quodlibetalia, que, como sugere a denominação, resultaram de compilado das questiones quodlibetatis. Referidas obras eram consequência de exercício de fixação doutrinária das liçôes de filosofia ou teologia, especialmente as desenvolvidas durante o período do Natal e da Páscoa. Daí emergiram outras tantas obras literárias, destacando-se De Veritate, Summa Contra Gentiles e a própria Suma Teológica, todas de Tomás de Aquino. Roberto Grosseteste (1168 a 1253) editou a Summa Philosophica, exemplar estudioso e responsável pela tradução mais perfeita da Ética a Nicômaco de Aristóteles, já que dominava bem o grego. (CHALMETA, 2002, p. 95).

Não é de confundir as glosas e silogismos escolásticos com sofismas. Estes ocuparam lugar na escolástica unicamente para basear a distinção entre falácias e heresias e a verdade teológico-filosófica da escolástica tomista ${ }^{6}$. Assim, não é lícito vislumbrar defeitos no

5 Os glosadores eram estudiosos que escreviam comentários (glosas) ao longo dos textos estudados. Destacaram-se os comentadores (glosadores) do Corpus Iuris Civilis (corpo de direito civil), também chamado Código de Justiniano, obra jurídica fundamental, publicada entre os anos 529 e 534 por ordem do Imperador bizantino Justiniano I.

6 Os sofistas se compunham de grupos de mestres que viajavam de cidade em cidade realizando apariçóes públicas (discursos etc) para atrair estudantes, de quem cobravam taxas para oferecer-lhes educaçáo. 
ensino universitário informado pela escolástica medieval nesse aspecto. Como sugere Ullmann (2000, p. 65), qualquer eventual defeito nesse sentido talvez não passe de confusão cometida entre os métodos e discussóes empreendidos no ensino escolástico e os sofismas que resultaram superados pelas verdades cientificamente alcançadas pelos mestres medievais, especialmente por Tomás de Aquino.

\section{Conclusões}

A eficiência do método escolástico de ensino é sensível, bem constatado que o ensino da atualidade o tem adotado, em que pese com algumas mitigaçóes. Seja nas escolas primárias, secundárias, no nível científico ou nas universidades em geral, enfim, o método escolástico era, como é, garantia de êxito para os verdadeiramente comprometidos com o aprendizado. Prova maior da eficiência, proveito e utilidade dos métodos medievais de ensino está nas oscilaçôes do que atualmente se tem denominado ensino à distância, tão decantado e idealizado como alternativa aos métodos tradicionais advindos desde a escolástica medieval, e que se destacam pela ausência de participação física e presencial nos auditórios e salas de aula. Podemos afirmar, não sem receio de censura, que nenhum outro método de ensino e de educação formal terá autoridade bastante para superar esses métodos adotados pelos estudiosos medievais. Mesmo podendo admitir-se refinamentos, o método escolástico ora focalizado jamais poderá ser inteiramente esquecido em qualquer tema sério de ensino e educação, em qualquer nível.

$\mathrm{O}$ ensino na atualidade tem-se revelado ineficiente e evasivo exatamente porque se busca, em vão, o emprego de métodos ditos "modernos" e "alternativos" de ensino, olvidando-se inadvertida ou intencionalmente dos insuperáveis bons resultados que o ensino tradicional presencial e participativo angariou desde o Medievo. O exemplo não é a melhor forma de convencer; é a única. E isso pressupóe admitir que o método de ensino escolástico-tomista é alvissareiro em tema de ensino nas academias e universidades.

\section{Referências}

AQUINO, Felipe. A igreja e o ensino na Idade Média. Disponível em http://www.pastoralis.com.br/pastoralis/html/modules/smartsection/item.php?itemid=286. Acesso em 10.09.2009.

O foco central de seus ensinamentos concentrava-se no logos ou discurso, com foco em estratégias de argumentaçáo. Os mestres sofistas alegavam que podiam "melhorar" seus discípulos, ou, em outras palavras, que a "virtude” seria passível de ser ensinada. Protágoras (481 a.C.-420 a.C.), Górgias (483 a.C.-376 a.C.), e Isócrates (436 a.C.-338 a.C.) estão entre os primeiros sofistas conhecidos (Cf. Escola sofista. Disponível em http://pt.wikipedia.org/wiki/Escola_sof\%C3\%ADstica. Acesso em 08.09.2009). 
AQUINO, Tomás de. Suma de teología, parte I-II, edición dirigida y traducida por los regentes de estudios de las provincias dominicanas de Espańa. Colaboradores: Ángel Martínez, Donato González, Luis Lopes de las Heras, Jesús M. Rodríguez Arias, Rafael Larrañeta, Victorino Rodríguez, Antonio Sanchís, Esteban Pérez, Antonio Osuna, Niceto Blázquez, Ramón Hernández. Madrid: Biblioteca de Autores Cristianos, 2001.

ASZTALOS, Monika. A faculdade de teologia. Uma história da universidade na Europa, coord. geral da edição Walter Rüegg, vol. I. As universidades na idade média, coord. de edição Hilde de Ridder-Syruoeus, Lisboa: Imprensa Nacional, Casa da Moeda, 1996.

BELLOMO, Manlio. Società e istituzioni in Italia dal medioevo agli inizi dell'età moderna, Roma: Ed. Roma, 1997.

CARPINTERO, Francisco. Justicia y ley natural: Tomás de Aquino y los otros escolásticos, Madrid: Servicio de Publicaciones de la Facultad de Derecho de la Universidade Complutense de Madrid, 2004.

CHALMETA, Gabriel. La justicia política en Tomás de Aquino. Una interpretación del bien comun político, Pamplona: EUNSA, 2002.

CHEVALIER, Jacques. Saint Thomas d'Aquin et son époque. Histoire de la pensée: la pensée chrétienne, vol. II, Paris: Flammarion Éditeur, 1956.

LISBOA, Maria da Graça Cavalcante. A ideia de universidade no Brasil, Porto Alegre: Edições EST, 1993.

PÉPIN, Jean. São Tomás de Aquino e a filosofia do século XIII. História da filosofia. De Platão a São Tomás de Aquino, vol. I, trad. de Afonso Casais Ribeiro, Linda Xavier e Manuel L. Agostinho, Lisboa: Dom Quixote, 1995.

SANTIDRIAN, Pedro. Tomás de Aquino, Barcelona: Urbion-Hyspamerica, 1983.

SARAIVA, José Antônio. História da cultura em Portugal, Lisboa: Editora Jornal do Foro, vol. I, 1950.

SERTILLANGES, Antonin-Dalmace. Santo Tomás de Aquino, trad. de José Luiz de Izquierdo Hernández, vol. 1, Buenos Ayres: Descléé, 1946.

TORRELL, Jean-Pierre. Iniciação a Santo Tomás de Aquino: sua pessoa e obra, trad. de Luiz Paulo Rouanet, 2a ed., São Paulo: Ediçóes Loyola, 2004.

VIEHWEG, Theodor. Tópica y jurisprudencia, trad. de Luis Díez Picazo, Madrid: Taurus, 1986.

ULLMANN, Reinholdo Aloysio. A universidade medieval, 2a ed., Porto Alegre: EDIPUCRS, 2000. 